\title{
SEM1 Gene
}

National Cancer Institute

\section{Source}

National Cancer Institute. SEM1 Gene. NCI Thesaurus. Code C20916.

This gene is involved in the ATP-dependent degradation of ubiquitinated proteins. 